\section{Connecting new farmers to place, agroecology, and community through a bilingual organic farm incubator}

\author{
Katherine Selting Smith, ${ }^{a} *$ Marcia Ostrom, ${ }^{b}$ \\ Donald McMoran, ${ }^{c}$ and Lynne Carpenter-Boggs ${ }^{d}$ \\ Washington State University
}

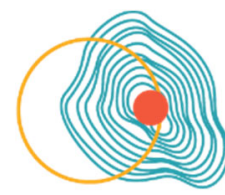

PLACE-BASED FOOD SYSTEMS CONFERENCE: Making the Case, Making it Happen August 9-10th, 2018

Submitted December 14, 2018 / Revised January 26 and February 22, 2019 / Accepted February 24, 2019 /

Published online June 6, 2019

Citation: Smith, K. S., Ostrom, M., McMoran, D., \& Carpenter-Boggs, L. (2019). Connecting new farmers to place, agroecology and community through a bilingual organic farm incubator. Journal of Agriculture, Food Systems, and Community Development, 9(Suppl. 1), 111-124. https://doi.org/10.5304/jafscd.2019.091.030

Copyright (C 2019 by the Authors. Published by the Lyson Center for Civic Agriculture and Food Systems. Open access under CC-BY license.

\begin{abstract}
Renewed public interest in the localized dimensions of food and farming systems offers opportunities for citizens to become more engaged in decision making about how their food is produced, distributed, and consumed, and, for all these actions, by whom. This paper explores an initiative designed to reinvigorate the production components of a place-based, regional food system through connecting diverse aspiring entrepreneurial

a $*$ Corresponding author: Katherine Selting Smith, School of Environment, Washington State University Skagit County Extension; 11768 Westar Lane; Burlington, WA 98223 USA; +1-360-428-4270; kate.smith@wsu.edu

b Marcia Ostrom, School of Environment, Washington State University; 1100 North Western Avenue, Wenatchee, WA 98801 USA; +1-509-293-8799; mrostrom@wsu.edu

c Donald McMoran, Agriculture and Natural Resources, Washington State University Skagit County Extension; 11768 Westar Lane; Burlington, WA 98223 USA; +1-360-428-4270; dmcmoran@wsu.edu
\end{abstract}

farmers, nonprofit organizations, land grant university faculty, and food consumers around shared values. The characteristics that distinguish valuesbased food systems can be sets of values associated with environmentally sustainable production practices, the qualities of the food, the distribution of the food, and/or relationships with particular farmers and places (Ostrom, DeMaster, Noe, \& Schermer, 2017). Based on interviews and participant observation, our participatory research with the Viva Farms bilingual farm incubator program

\footnotetext{
d Lynne Carpenter-Boggs, Department of Crop and Soil Sciences, Washington State University; 247 Johnson Hall; Pullman, WA 99164 USA; +1-509-335-1553; $\underline{\operatorname{lcboggs} @ \text { wsu.edu }}$

\section{Funding Disclosure}

The research for this paper was supported in part by funding from the Specialty Crops Block Grant Program, Washington State Department of Agriculture \#K1267 (2013-2016). The views expressed in this paper do not necessarily reflect those of the funder.
} 
explores the role of place, social, and environmental values, and social learning in launching an incoming generation of women, immigrant, and lowincome farmers. These themes have not been previously explored in the literature in relation to the success of new entry farmer initiatives. As of 2016, six years into the program, our findings show that 77 percent of past program participants were still farming in the same region, using agroecological farming practices and employing place-based marketing strategies.

\section{Keywords}

Agroecology, Beginning Farmers, Bilingual Education, Community Food Systems, Farm Incubator, Organic Farming, Place-based Food Systems, Values-based Food Systems, Food Sovereignty

\section{Introduction}

Agriculture is central to the economy of the Northwestern United States. With rich soils, engineered irrigation systems, and a wide range of microclimate zones, Washington is the second most agriculturally diverse state in the U.S. in terms of the crops produced. An apparent landscape of plenty with over US\$10 billion in annual production value (U.S. Department of Agriculture, National Agricultural Statistics Service [USDA NASS], 2017), Washington agriculture has focused on agroexports that closely articulate with global markets, encourage agricultural consolidation and industrialization, and draw an international labor force. However, such agricultural restructuring has led to steadily declining numbers of profitable small and mid-sized farms, an aging farmer demographic, and insecure agricultural working conditions. In Washington State, approximately half of all farmers are over the age of 60 , and only 6.8 percent are under the age of 35 (USDA NASS 2012).

In keeping with movements to counter the negative effects of agricultural and food system globalization emerging around the world, Washington residents are responding to the challenges in different ways. Some of these ways are explicitly oppositional to each other and others are focused on the creation of alternative models (McMichael, 2014). Aligning with the observation by food system scholar McMichael (2014) that in response to current food system crises and contradictions "communities are developing adaptive strategies that intersect with food sovereignty visioning, whether they call it food sovereignty or not," (p. 952) we propose a case study of one such response. Regardless of how they themselves characterize their participation, a renewed public interest in local foods in Washington appears to offer new opportunities for citizens to become more engaged in decision making about how their food is produced, distributed, and consumed, and by whom. When randomly surveyed, most Washington consumers expressed a strong desire to support local farmers with their food purchases (Ostrom, 2017). While promising, transformation toward a more sustainable agriculture will require actions across the food system, encompassing research and education to on-farm practices to market development to policy reform, all going well beyond consumers that make more intentional food purchasing choices. As articulated by a wide range of food system critiques, solutions to modern food system problems will require both producer and consumer engagement in ensuring equitable access to farming resources and markets, as well as the restoration of agroecosystems (DeLind, 2011; Ostrom, 2015; Reganold et al., 2011). And, while it may appear at face value that consumers of alternative foods are primarily concerned with their own personal health, nutrition, and gastronomic satisfaction, when asked specifically about how they view their food choices, random sample survey research with Washington residents has shown that many do see connections among their food purchasing choices and aspects of ecological, economic, and farmers' well-being. However, these associations emerge most clearly in relation to specific places rather than in relation to social or political movements (Ostrom, 2006). This survey research found that "identification with a locality" offered prospects for "building common ground among consumer and farmer" interests related to food production and distribution (Ostrom, 2006, p. 77). This is significant because, as Marsden (2012) and others contend, many agroecological solutions to farming problems appear to be most effective if they are "place-based" and designed in response to specific ecological, economic, social, and cultural settings 
(Méndez, Bacon, \& Cohen, 2013). This builds on earlier observations by Flora (1998) that attachment to place forms a necessary foundation for generating community capital and sets the stage for Marsden's (2012) ideas about adaptive capacity building through generating place-based "communities of food practice" that support innovative, new institution-building and governance at a scalable level of "city-regions" (pp. 271-272). Finally, from the standpoint of redesigning agrifood systems based on "agroecological principles," (Méndez et al., 2013, p. 10) to optimize agroecosystem health, sustainable livelihoods, and food system self-determination, change strategies may be most effective if they are participatory, bottom-up, politically engaged, and action-oriented. Further such systems will need to be adjusted to particular environments and "facilitate inter-generational transfers" (Méndez et al., 2013, p. 11). Thus, food system values that evolve in relation to particular places and their residents may encourage collective action strategies that directly engage concerns about environmental sustainability and the wellbeing of farmers and farmworkers at a manageable scale (Ostrom 2006, 2017).

Farm incubators, programs that aim to reduce barriers to entry for beginning farmers, can be seen as one manifestation of food-sovereignty related movements that are concerned not only with the quality and secure availability of food, but also with how and where the food will be produced and by whom (McMichael, 2014; Méndez et al., 2013; Ostrom, 2017). They offer one example of local community-based action to counter global market forces by reconnecting food, farms, and communities through the support of new farmers with access to land, equipment, direct markets, training and capital attached to a particular place (Lelekacs, O'Sullivan, Morris, \& Creamer, 2014). In 2012 the National Incubator Farm Training Initiative counted 61 farm incubator programs in the U.S.a number that grew substantially to 220 programs in 2016 (New Entry Sustainable Farming Project, 2016). The rise in incubator programs could be viewed as one expression of growing public awareness that the future of agroecosystems and community-based food systems is critically dependent on the access to resources, knowledge, skills, and strategies of incoming farmers. However, it is unclear how successfully these programs can realize environmental and social sustainability values and whether the broad-based community support engendered through these programs can be translated into greater viability for new farmers.

In this paper, we examine whether crossorganizational partnerships, formed with a connection to a particular place, a commitment to farmer and farmworker well-being, and a commitment to agroecological principals, can foster environmental stewardship and the strong social connections and infrastructure development required to support the next generation of farmers. Our participatory research with the Viva Farms bilingual farm incubator program participants seeks to understand the role of place, community, and social and environmental values from the perspective of beginning, women, immigrant, and low-income farmers. We employ a concept of community that is based on connections to "place" as observed by Flora (1998) and draws from a rich community development literature that conceives of community as both a physical space and a dynamic, interactive social space as elaborated by Liepins (2000) and Flora (2001). Thus, the project under study operates within a particular social space that encompasses a web of relationships, values, aspirations, and identities that inspire various actors and organizations to form commitments to the project and to each other, thus ultimately building and reinforcing a form of social capital (Flora, 1998). However, when referring to the land-based production and learning site offered through the incubator, we focus on the physical location of Skagit County, Washington, where a network of resource providers, including local government and nonprofit entities, have secured the material means of production, financial resources, and the educational facilities needed for the project to operate. When referring to marketing, sales, and consumption networks, we expand our physical geographical context to include the greater regional community of consumers and buyers in the Puget Sound Region between Seattle and Bellingham.

Our research aspires to contribute to the body of knowledge developing around beginning farmer training programs and farm incubator programs by 
more closely examining their socio-ecological dimensions. While there has been rapid growth in the numbers of beginning farmer training programs, little systematic research has been done either on the unique features of educational approaches that are embedded in strong community support networks, or on the role of these programs in developing alternative, sustainable, and inclusive community food and farming systems (Niewolny \& Lillard, 2010). Much of the literature has documented the rise in incubator farm programs and the practical aspects of program models and design (Lelekacs et al., 2014; Melone, 2006; Overton, 2014; Winther \& Overton, 2013). Several have considered the role that farm incubator programs can play in providing opportunities for diverse beginning farmers to engage in regional food system economies (Brodt, Feenstra, Kozloff, Klonsky, \& Tourte, 2006; Overton, 2014). Additionally, researchers have noted that while Extension may be well positioned to support farm incubators, programs may be more successful if they are not directly operated by an educational institution (Flora, Emery, Thompson, Prado-Meza, \& Flora, 2012; Lelekacs et al., 2014). Calo and DeMaster (2016) identify the need for continued support after the incubator program and recognition that such programs alone cannot solve issues of land access for socially disadvantaged and beginning farmers. There are complex socio-cultural and economic barriers including race and power relations beneath the barriers of price and availability (Calo \& DeMaster, 2016). Gaps remain in understanding the extent to which incubator programs can address issues of equitable access to farming, how farm incubator programs influence participant farming and marketing practices and how farmer values related to environmental sustainability and community connections can be cultivated (Brodt et al., 2006; Ewert, 2012; Niewolny \& Lillard, 2010). We aim to build on the existing literature by exploring themes of place, community linkages, inclusive learning models, and environmental farming practices through the case study of Viva Farms to answer questions about the role of farm incubators as a broad-based community change strategy to enhance food system sustainability.

\section{Incubator Program Background}

Viva Farms is a nonprofit organization operating a bilingual, certified organic farm incubator program on 78 acres of land in Skagit County, Washington, approximately 70 miles north of Seattle (Viva Farms, n.d.). The Viva Farms farm incubator program was founded on an initial 33-acre (13.4 hectare) property through a cross-organizational collaboration in 2010 among the project organizers: Washington State University (WSU) Skagit County Extension, the Port of Skagit, and several other community funders. The collaborators came together with the goal of investing in the placebased regional food system through the support of new entry farmers. With the mission to launch the next generation of farmers and reduce barriers to entry for beginning farmers, Viva Farms provides access to the top five essentials for farming including land, infrastructure, markets, capital, and training (Ewert, 2012). In 2017, Viva Farms purchased a 45 -acre (18.2 ha) property also located in Skagit County to expand available land for participants. In 2018 Viva Farms launched a new additional incubator site in King County, in the greater Seattle metropolitan area.

The Viva Farms incubator program is open to all beginning farmers who qualify, and is offered in English and Spanish to meet the needs of the local agricultural population in Skagit County. With a long history of Latino farmworkers and a growing number of Latino farm operators in Washington state, there is a demonstrated need for bilingual educational programs (Ostrom \& Donovan, 2016). Strategic outreach to the Latino community is conducted through collaboration with WSU Extension. Infrastructure includes shared farm equipment, access to a greenhouse, barn storage space, water, cooler, wash pack station, and computer access. In addition to the hands-on learning that participants acquire through growing and managing their own parcels, workshops are offered throughout the year on business management, marketing, food safety, and agroecological production practices including cover cropping, pollinator habitat, and soils management. In 2016, Viva Farms began facilitating the Practicum in Sustainable Agriculture, a hands-on farming course for Viva Farms participants during their first year before 
leasing their own farm plot, offered for credit in collaboration with the Skagit Valley College Sustainable Agriculture Education Program. Viva Farms operates a wholesale marketing program and a Community Supported Agriculture (CSA) program where participant farmers learn how to market their produce. Viva Farms wholesale markets include restaurants, grocery stores, food cooperatives, schools, daycares, and businesses. Farmers also market their own produce through local farmers markets, CSA, and wholesale accounts. Farmers are expected to become increasingly independent over a five-year trajectory.

\section{Farm Incubator Program Models and Adult Learning} In assessing how farm incubator programs serve as a place-based food system model to foster environmental stewardship among new entry farmers, we found it important to look at how adult learning influences adoption of agroecological practices. While it has been found that farmers' adoption of practices is influenced by production yields and costs (TerAvest, Carpenter-Boggs, Thierfelder, \& Reganold, 2015), a review of the literature shows that adoption of agroecological practices depends not only on the innovations and practices presented, but also on the social networks that support the implementation of those innovations and behavior changes (Kroma, 2006). Adults have accumulated knowledge and experience that they apply to the learning process (Kroma, 2006), constantly reflecting and rethinking as part of learning and decision making (Barrantes \& Yagüe, 2015). Social learning brings together knowledge through relationships and interactions with others over time (Flora, 1998). Because of this, agroecological behavior change requires not only technological innovations and practices, but also effective education methods and social support networks (Röling \& Wagemakers, 1998; Kroma, 2006). Both internationally and nationally, NGOs and social networks play a large role in disseminating information about organic agriculture, influencing adoption of those practices (Goldberger, 2008).

Additionally, agroecology is, at its roots, a participatory and action-oriented approach that recognizes farmers' own knowledge and expertise in understanding the complexities of ecosystem interactions (Gliessman, 2014; Méndez et al., 2013; Wezel et al., 2009). Through this lens, hands-on participatory methods that facilitate an environment where farmers can experiment, and then relate those experiences within a social network, can lead to learning and innovations in agroecological resource management (Barrantes \& Yagüe, 2015; Hassanein \& Kloppenburg, 1995; Kroma, 2006). This is especially important for participant groups with a diversity of educational experiences, as hands-on learning through field programming has been shown as an effective educational strategy accessible to all, even those with limited or low levels of formal education (Davis et al., 2012). Although participatory methods and relationships are often emphasized in international projects, recently they have been recognized as important components of community development projects in the United States (Nerbonne \& Lentz, 2003).

As many farm incubator programs have been created, one important component of these programs is the teaching of agroecological practices to new farmers as an expression of environmental values in agricultural production. For example, many beginning farmer programs focus on ecologically sustainable production methods that include organic amendments, cover cropping, crop rotations, pollinator hedgerows with native plants, compost and manure to increase organic soil matter, and other practices that relate to the local ecological systems of the place where they farm. Indeed, most farm incubators teach sustainable techniques as well as conservation-minded decision-making strategies for their new farmer participants (Melone, 2006). Beyond the direct ecological impact of these adopted practices, programs that connect people to place have the power to develop an ecological conscience in the next generation of farmers and consumers (Herman, 2015). Immersion in agroecological practices at the beginning of farmers' careers could result in the normalization of these practices as a standard over time, increasing the ecological integrity of place-based food systems. While farmer values guide production practices, it is important to recognize that industry and market forces including the low market value of produce and the high costs of land and labor challenge whether a farmer can 
maintain agroecological production practices when faced with an unsustainable economic reality (Guthman, 2004).

\section{Research Methods}

We used qualitative and quantitative methods to conduct this in-depth case study in 2016, through interviews and surveys with current and past participants, participant observation, and Viva Farms staff interviews. The selection of our interview participants included all current and past participants. Interview and survey questions were patterned after the Agriculture and Land-Based Training Association (ALBA) End of Year Interviews and a study of the University of Santa Cruz Apprenticeship in Ecological Horticulture (Perez, Parr, \& Beckett, 2010).

Using the preferred language and communication format of the participants, Viva Farms staff contacted past Viva Farms participants via phone, text, and/or email in May 2016 to share the purpose of the study and invite them to participate in a scheduled interview at their farm. In June 2016, we sent follow-up emails and phone calls. Additional follow-up included phone calls, voice messages, text messages, email invitations, and contact again from Viva Farms and from the previous leadership. The interviews consisted of a field visit and a structured interview that was audio-recorded with participant consent. We conducted structured interviews in person and over the phone when necessary with eight previous participants and thirteen current participants during spring and summer 2016. Interviews ranged from 20 to 60 minutes. Interviews were conducted in Spanish or English according to the preferences of the participant. Secondary data was collected through survey results and Viva Farms materials, including responses from 2015 End of Year Surveys conducted in November and December with fourteen Viva Farms participants.

As a program partner at WSU Extension, our case study incorporated ongoing participant observation that included shadowing farmers during operations, supporting farmers in farm management and providing Spanish interpretation for monthly Viva Farmer meetings, allowing triangulation of self-reported data, and facilitating in the development of codes and themes for analysis (Jorgensen, 2015). Participant observation also allowed the growth of trust with participants to develop in-depth farmer narratives.

According to Viva Farms records, 28 farm businesses participated in the program between 2010 and 2015. We were able to contact and conduct interviews with 22 of the 28 farm businesses, a response rate of 79 percent. Those 22 farm businesses were represented by 27 farmer participants, as several farms were operated by couples. The remaining six participant farms were unreachable through various outreach methods including phone, email, and contact with previous organizational leadership. Two past participants who were unreachable appear to be currently farming. There was no observable pattern or response bias in the reason for not participating in the evaluation. If the total is adjusted for the two phone numbers that could not receive messages, 22 of the 26 farmers who received invitations to participate in the study chose to do so. This leaves an adjusted response rate of 85 percent, which is quite high and increases the likelihood that these results are representative.

To address our research questions, we asked participants about the practices they used on their farms and what they felt were benefits of the program. From end of year survey results from 21 of the 22 respondent farm businesses, we measured self-reported utilization of agroecological practices in farming or gardening since participating at Viva Farms as an indicator of ecological stewardship of a place-in this case, the Skagit Valley of Western Washington. Surveyed practices included: water conservation; cover cropping; soil testing and nutrient management; utilization of practices that promote soil quality and health; physical, cultural, and biological controls for pest and disease management; planting of pollinator habitat; improved nutrient cycling; improved energy efficiency or green energy sources; use of approved organic inputs; crop rotation plan; nonuse of synthetic or petrochemicals; and other environmental sustainability practices. The Viva Farms program focuses education and technical support on these practices and requires some of these practices in the land lease. Interviews also 
documented participant demographics, acres farmed, diversity of crops planted, and organic certification by each farm as indicators of ecological integrity and environmental values. We asked open-ended and structured questions about the value of the program to explore how values of place and community were expressed by participants. Viva Farms also uses an annual "SelfAssessment of Skills" for participants that evaluates the knowledge and implementation of various agroecological production practices. Qualitative data were analyzed using comparative coding to identify common themes and explore the range of responses.

\section{Results}

The Viva Farms participants self-identified their gender, ethnicity, education level, and family class demographics (Table 1). Latino and Indigenous Latino participants identified their primary language as a language other than English, including Spanish and Mixtec. We decided to include a "Latino and Indigenous" category even though the census does not have this listed option, as many of the participants shared their ethnicity as Mexican Indigenous. Participant education level ranged from $2^{\text {nd }}$ grade to graduate degree, and the average farmer age was 40.2 years. As a point of comparison, Skagit County farm operator demographics indicate that 23 percent of farm operators are female, .03 percent are of Spanish, Hispanic, or Latino Origin, and the average age is 58.4 years (USDA NASS, 2012).

Of the participant farms interviewed, 17 reported farming in 2015 on 25.28 acres (10.23 ha) total ranging from .03 to 5 acres (.01 to $2 \mathrm{ha}$ ) in Skagit County and adjacent Whatcom County. Crop diversity grown by participants ranged from 1 to 100 , and included mixed annual vegetables, perennial vegetables, perennial berries, herbs, flowers, and grains with an average diversity of 17 crops per farm (Figure 1). Of the 16 growers $(73 \%)$ who operated a farm business in 2015, five worked on the farm full-time seasonally, while 11 worked on the farm part-time. When asked to "generally describe your farm business in 2015," participants used terms explaining their practices including "organic," "diverse," "sustainable," "biodynamic," "permaculture," "low-input", and "natural practices." One participant shared that the reason they came to Viva Farms to start a farm business was because "farming is a means to impact the world, to live according to morals." While participants often bring values with them when they begin, the program appears to serve as a vehicle to develop preexisting values and a means to take action on those values. Research by Minkoff-Zern (2012) on indigenous Oaxacan farmers in California suggests that while farmers bring with them their traditional ecological knowledge and values, they combine those with practices they learn working on farms in

Table 1. Viva Farms Farm Owner/Operator Participant Demographics

\begin{tabular}{|c|c|c|}
\hline & $N$ & Percent \\
\hline \multicolumn{3}{|l|}{ Gender $(n=27)$} \\
\hline Female & 11 & $40.7 \%$ \\
\hline Male & 16 & $59.3 \%$ \\
\hline \multicolumn{3}{|l|}{ Ethnicity $(n=27)$} \\
\hline African American & 0 & $0.0 \%$ \\
\hline Asian American & 1 & $3.7 \%$ \\
\hline European American & 13 & $48.1 \%$ \\
\hline Hispanic/Latino & 6 & $22.2 \%$ \\
\hline Indigenous and Latino & 6 & $22.2 \%$ \\
\hline Other & 1 & $3.7 \%$ \\
\hline \multicolumn{3}{|l|}{ Age $(n=23)$} \\
\hline Less than 35 years & 6 & $26.1 \%$ \\
\hline 35 to 64 years & 17 & $73.9 \%$ \\
\hline $65+$ years & & $0.0 \%$ \\
\hline \multicolumn{3}{|l|}{ Education Level $(n=26)$} \\
\hline Less than High School & 12 & $46.2 \%$ \\
\hline Some College or Associates Degree & 2 & $7.7 \%$ \\
\hline College Graduate & 8 & $30.8 \%$ \\
\hline Master's Degree & 4 & $15.4 \%$ \\
\hline $\mathrm{PhD}$ & 0 & $0.0 \%$ \\
\hline \multicolumn{3}{|l|}{ Family Class $(n=24)$} \\
\hline Wealthy & 0 & $0.0 \%$ \\
\hline Upper Middle Class & 1 & $4.2 \%$ \\
\hline Middle Class & 7 & $29.2 \%$ \\
\hline Working Class & 9 & $37.5 \%$ \\
\hline Low Income/poor & 6 & $25.0 \%$ \\
\hline Don't know & 1 & $4.2 \%$ \\
\hline
\end{tabular}


Figure 1. Crop Diversity, Acreage and Organic Certification of 2015 Participant Farms $(N=17)$

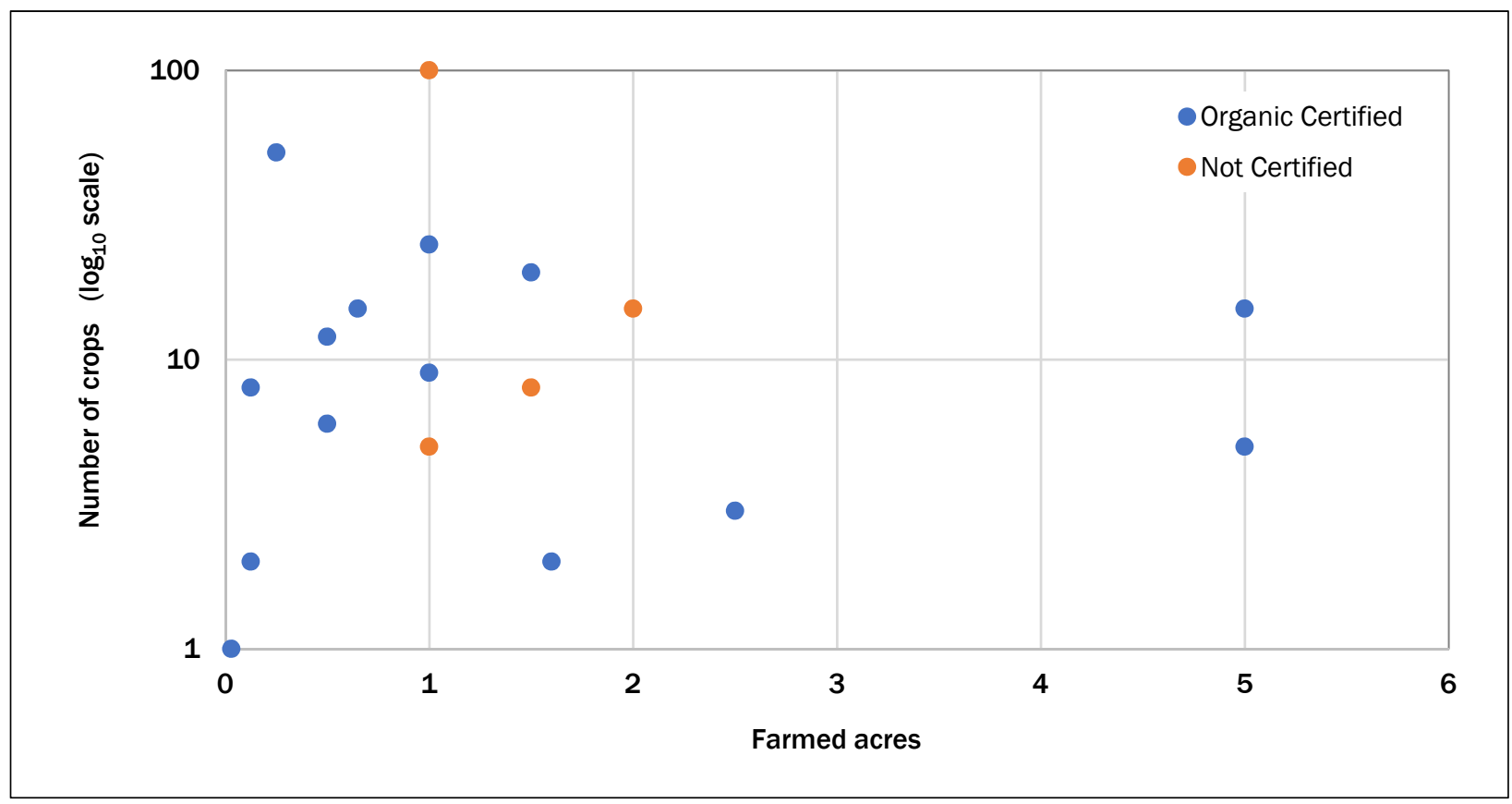

California to form practices that best fit that specific ecosystem and place.

Exploring the adoption of agroecological practices, we asked respondents "since participating at Viva Farms, have you incorporated any of the following into your farming or gardening?" All Viva Farms participants reported implementing some agroecological production practices on their farms or gardens (Table 2). For the 14 farms growing on Viva Farms land, some practices are a requirement of the Viva Farms lease, including the use of approved organic inputs, non-use of synthetic or petrochemicals, cover cropping, and crop rotation. Several participants who reported not utilizing a given practice expressed future plans for implementation. From observations and partici-
Table 2. Agroecological Production Practices Adopted by Viva Farms Incubator Program Participants $(N=21)$

\begin{tabular}{lcc}
\hline Practice & Positive & Percent \\
\hline Water Conservation Practices & 21 & $100.0 \%$ \\
Use of Only Approved Organic Inputs* & 21 & $100.0 \%$ \\
Utilization of Practices that Promote Soil Quality/Health & 20 & $95.2 \%$ \\
Non-use of Synthetic or Petrochemicals* & 20 & $95.2 \%$ \\
Improved Nutrient Cycling & 19 & $90.5 \%$ \\
Soil Testing and Nutrient Management & 18 & $85.7 \%$ \\
Cover Cropping* & 16 & $76.2 \%$ \\
Physical, Cultural and Biological Controls for Pest and Disease & 16 & $76.2 \%$ \\
Planting of Pollinator Habitat & 16 & $76.2 \%$ \\
Crop Rotation Plan* & 15 & $71.4 \%$ \\
Improved Energy Efficiency/Green Energy Sources & 7 & $33.0 \%$ \\
Individual Farm Organic Certification & 3 & $14.5 \%$ \\
\hline
\end{tabular}

*Required practice for those farming at Viva Farms 
currently using those practices.

Of the 17 farms in operation in 2015, 15 were certified organic, including all farms operating at Viva Farms under the umbrella of Viva Farms Organic Certification and one farm off Viva Farms property. Twelve participant farms reported planning to certify individually in the future. The Viva Farms lease contract requires all current participants to comply with organic certification requirements for production and record keeping under the Viva Farms Group Organic Certification. In decisions to obtain their own organic certification, farmers expressed that their decision was market driven. All participants, including those who did not organic certify their farms, stated that they practice non-use of synthetic and petrochemicals on their farms. Through participant observation and unstructured interviews, several participants said that they wanted to farm organically for their own health and the health of their family and workers. For example, one farmer shared that after working on conventional farms for years, she wanted to begin her own farm organically to reduce pesticide exposure while she and her family were working in the fields. Beginning her own farm business gave her the power to make those management decisions.

Ongoing participant observation revealed other components of the Viva Farms incubator program that influenced the adoption of agroecological practices by participants. These included organized yearly group purchasing of winter cover crop seed and fertilizer and shared equipment for reduced tillage, and seeding and incorporating cover crops. The Viva Farms lease contract requires cover cropping of leased parcels not planted in perennial crops. Viva Farms also organizes soil and water testing for the property, sharing the results with the growers to emphasize and demonstrate the importance of these components for on-farm nutrient management. In 2016 Viva Farms participated in a restoration project onsite to replant the waterway running through the property, serving as a demonstration restoration buffer zone. Replanting included native species to attract and provide habitat for pollinators. Following the replanting of the buffer, we observed the informal sharing of flower seeds and tubers between farmers for increased pollinator habitat within their own plots.

We coded participant responses to open-ended questions about the benefits of the program $(N=20)$ and identified common themes. The most common cited benefits were "the value of education" (60 percent), "learning from other participants or staff as neighbors and friends" (55 percent), "creation of community while farming" (35 percent), and "bilingual English/Spanish component of the program" (30 percent), identified by both native and non-native English speakers. These themes, combined with the finding that the majority of participants implemented agroecological practices, highlight the value of the social network and of bilingual education to support social learning and implementation of production practices by beginning farmers.

In this quote from an interview discussing what it is like farming alongside others at Viva Farms, this farmer highlighted the importance of social learning to the program model.

If you want to learn more, I think that you have to see it as a personal benefit, but if you aren't interested in moving forward and learning more, then not really. But if you are interested in flying really high, then yes, it is beneficial. Because you are going to learn from others. And others are going to learn from you.

This quote, translated from Spanish, exemplifies the sharing of knowledge through relationships and interactions with others over time (Flora, 1998).

Through participant and program observation, we saw increased marketplace access and representation for participant farmers. Buyers from regional food coop stores, food hubs, restaurants, and regional stores of national chains purchased product from both the Viva Farms wholesale program as well as individual Viva farmers. Regional farmers markets and buyers began actively recruiting Latino farmers to sell in their markets. CSA subscriptions from Viva Farms more than doubled from year one to year two, as more businesses throughout the region offered to host drop sites for individuals to pick up their boxes of 
produce grown by beginning farmers in the program.

We also observed how cross-organizational collaboration has continued through the development of the Viva Farms program. Viva Farms and WSU Skagit County Extension continue to collaborate on programming, grant projects, and individual farmer support. WSU Skagit County Extension offers courses to assist potential farmers in preparing for beginning the Viva Farms program, including the Cultivating Success courses and Tractor Safety course. Local government continues support through the continued lease of land to Viva Farms through the Port of Skagit and has expressed a commitment to support beginning farmer development and local agriculture. To provide more land for participants and increase the stability of land tenure, Viva Farms has also built partnerships with a regional land trust that assisted in providing the down payment for the purchase of the 45-acre (18.2 ha) land purchase in Skagit County. Local banks have collaborated to offer capital access for participants, and a farmland preservation organization has begun support to assist in linking farmers to farmland after participation. Access to land following participation remains a weakness. However, the incubator is addressing this in a small way through these collaborations and through supporting farmers to gain the management experience and skills to apply for and obtain farm loans. Staff recognized the importance of these community partnerships in the development of the program.

\section{The Role of Incubators in Building Sustainable Community Food Movements}

Through this case study, we observed how a placebased solution to a food systems problem in the form of an incubator program can be designed in a way that both respond to the needs of communities and build on and enhance their existing ecological, economic, and social assets. The Viva Farms participants outpaced state and national demographics for beginning farmers in racial and ethnic diversity, gender, and age with a lower average age, a higher percentage of women farmers, and a higher percentage of minority farmers (USDA NASS, 2014). Additionally, these new business owners were supported through new and existing market spaces such as farmers markets, food coops, grocery stores, and food hubs. This shows community support for the economic sustainability of the producers. All program participants who responded were using ecological farming practices taught in the program curriculum, which improve environmental sustainability. These results suggest that in this case, when embedded in community collaboration and connections, a farm incubator program has the potential to foster more sustainable social, economic, and environmental outcome.

Our quantitative data on participant-reported implementation of agroecological practices showed widespread use and adoption of these practices. The data also suggest that the program requirements and educational support of the farm incubator program provide the structure for participant farmers to enact agroecological values through their farming and marketing practices in connection to a specific geographic place, as those participants continued to farm in the same region. The production and marketing practices that Viva Farms employs in their training and technical assistance clearly influenced the production and marketing practices that the participants employ. This demonstrates the important role that the structure provided by the incubator program can play in supporting the implementation of place-based agroecological practices, giving a beginning farmer the opportunity to experiment and then integrate the practices into their production system for future seasons. The high implementation rates of these practices indicated participants' expression of environmental values through the management of agroecological systems, which is then expressed to buyers and consumers through branding and storytelling. Future opportunities exist to research how buyers and consumers identify with both place and community when purchasing from Viva Farms and its farmers, and how they view themselves as partners in the development of a regional food system.

We found that social network created through participation at Viva Farms played a role in supporting the adoption of those practices through social learning. The themes from participant responses on the benefits of the program confirmed adult learning theory that social networks and social learning influence adoption and 
implementation. Farm incubator programs enable the social learning process through the intentional design of grouping farmers on one site to facilitate observation, reflection, knowledge sharing, experimentation, and implementation from one season to the next. This happens both through structured training and meetings, and occurs organically in the field. Those participants who said they plan to implement surveyed practices in the future demonstrate the need for programs and social networks that support beginning farmers over several seasons. Observations indicated that the adoption of practices in farming is a multiseason learning process, strengthening the importance of long-term social networks in supporting the increased implementation of agroecological practices.

Important to the transformation toward sustainable agriculture in this specific example, the hands-on incubator education model proves accessible for equipping beginning farmers with a wide range of educational experiences, including social learning, to become knowledgeable and skilled environmental stewards and business managers. The dissemination of information through the social network and hands-on training facilitated through the Viva Farms incubator program demonstrates the ability of this model to provide access to information that accommodates the diverse educational background range of participants. Increased access to markets for these beginning farmers, including many women and immigrant farmers, increases options for buyers and consumers to participate in a food system that reflects and values those farmers as important contributors to food systems. At a community level, this increased access enables the social movement around food to support values of social inclusion and environmental protection. It should also be noted that access to products from diverse producers does not always increase consumer purchasing from these producers as it has in this community (Cooper, 2018).

Our case study suggests the value of additional future research focused on the role of beginning farmer education programs in contributing to the environmental and social sustainability of commnity-based food systems. It also raises questions about the significance of the educational formats employed, including the capacity for welcoming and serving diverse farmer audiences, and the critical need for broad-based community engagement and support. If some of these same kinds of results emerge from other incubator projects in other locations, it would suggest that this model can be tailored to respond to the needs of particular communities and places. Beyond serving the obvious practical need to transition to the next generation of farmers, the model may offer an important means for engaging community food movement actors and concerned food consumers to participate in and support decision-making about by whom, where, and how food will be produced.

\section{Conclusions}

This case study suggests ways that community food system actors can engage with the production and social equity aspects of place-based food systems. Cross-organizational collaboration and support for diverse new entry farmers show promise for enhancing the ecological, economic, and social sustainability of community-based food systems. Our participatory research with the Viva Farms bilingual farm incubator program indicates initial success in educating and retaining beginning organic farmers, women farmers, and immigrant farmers. Several years out, a high percentage of past program participants are still farming and employ agroecological farming practices and place-based marketing strategies. The participatory, multiyear educational design of the incubator program facilitates strong peer social networking and ongoing social learning, which are unique attributes of models that support long-term implementation. If the outcomes from this example are similar to other incubator initiatives structured in similar ways, they would suggest that when values about food, place, and the environment are enacted collectively at a community level by a variety of actors working collaboratively, new farmers have a more realistic opportunity to succeed. Perhaps even more critically, with this model, aspiring farmers do not have to come from economically, socially, or racially privileged backgrounds to succeed. This intersects with the food sovereignty movement through equitable access to food production.

Our exploration of themes of place, commnity 
connections, social equity, and agroecological farming practices provides a contribution to the literature that details how farm incubator programs can influence participant farming practices and cultivate values related to environmental sustainability and community. Farm incubator programs support the development of beginning farmers by linking them to place via the social networks, knowledge set, and markets they become connected to through the program. Through crossorganizational collaboration, social networks are expanded, which in turn increases behavior change. By participating in the incubator program, farmers can experiment with agroecological techniques over several seasons, sharing and reflecting with other farmers and they can begin to learn about how to successfully employ community-based marketing strategies. Following participation, once they have launched to their own plots of land, farmers appear to maintain the social networks that they created to extend learning — with some years of experience utilizing these practices-making them effective beginning environmental stewards and direct marketers. The place-based farm incubator model prepares future farmers to create local networks of lasting relationships with farmer peers, farmer mentors, buyers, and consumers, while employing production approaches that steward the land in that place.

Continued research is needed to track how farmers who move onto their own land continue and develop their agroecological practices and expression of values and motivations over time. Considering that there continue to be challenges in land access after participation in the incubator program, long-term research will be critical determining the viability of this model. Future interviews with buyers of Viva Farms produce and participating producers could elaborate our case study to further explore the role that values-based food system development can play in agricultural sustainability. Comparisons of farm incubator programs with other types of programs and programs lengths could further clarify what is uniquely contributed by this model.

\section{Acknowledgments}

The authors wish to thank the farmers and staff at Viva Farms for their participation in this research.

\section{References}

Barrantes, C., \& Yagüe, J. L. (2015). Adults' education and agricultural innovation: A social learning approach. ProcediaSocial and Behavioral Sciences, 191, 163-168. https://doi.org/10.1016/i.sbspro.2015.04.387

Brodt, S., Feenstra, G., Kozloff, R., Klonsky, K., \& Tourte, L. (2006). Farmer-community connections and the future of ecological agriculture in California. Agriculture and Human Values, 23(1), 75-88. https://doi.org/10.1007/s10460-004-5870-y

Calo, A., \& De Master, K. T. (2016). After the incubator: Factors impeding land access along the path from farmworker to proprietor. Journal of Agriculture Food Systems, and Community Development, 6(2), 111-127. https://doi.org/10.5304/jafscd.2016.062.018

Cooper, D. (2018). Reframing food hubs; Food hubs, racial equity, and self-determination in the South. Atlanta, GA: Center for Social Inclusion. Retrieved from https://www.centerforsocialinclusion.org/wp-content/uploads/2018/04/ Reframing-Food-Hubs-Report-by-Dara-Cooper-for-Race-Forward-and-Center-for-Social-Inclusion.pdf

Davis, K., Nkonya, E., Kato, E., Mekonnen, D. A., Odendo, M., Miiro, R., \& Nkuba, J. (2012). Impact of farmer field schools on agricultural productivity and poverty in East Africa. World Development, 40(2), 402-413. https://doi.org/10.1016/j.worlddev.2011.05.019

DeLind, L. B. (2011). Are local food and the local food movement taking us where we want to go? Or are we hitching our wagons to the wrong stars? Agriculture and Human Values, 28(2), 273-283. https://doi.org/10.1007/s10460-010$\underline{9263-0}$

Ewert, B. M. (2012). Understanding incubator farms: Innovative programs in new farmer development (Master's thesis). University of Montana, Missoula, Montana. Retrieved from https://scholarworks.umt.edu/etd/1146/

Flora, C. (2001). Shifting agroecosystems and communities. In C. Flora (Ed.), Interactions between agroecosystems and rural communities (pp. 5-13). Boca Raton, FL: CRC Press. https://doi.org/10.1201/9781420041385 
Journal of Agriculture, Food Systems, and Community Development

ISSN: 2152-0801 online

https://www.foodsystemsjournal.org

Flora, J. L. (1998). Social capital and communities of place. Rural Sociology, 63(4), 481-506. https://doi.org/10.1111/i.1549-0831.1998.tb00689.x

Flora, J. L., Emery, M., Thompson, D., Prado-Meza, C. M., \& Flora, C. B. (2012). New immigrants in local food systems: Two Iowa cases. International Journal of Sociology of Agriculture and Food, 19(1), 119-134.

https://www.ijsaf.org/index.php/ijsaf

Gliessman, S. R. (2014). Agroecology : The ecology of sustainable food systems. Boca Raton, FL: CRC Press. https://doi.org/10.1201/b17881

Goldberger, J. R. (2008). Diffusion and adoption of non-certified organic agriculture: A case study from semi-arid Makueni District, Kenya. Journal of Sustainable Agriculture, 32(4), 531-564. https://doi.org/10.1080/10440040802257371

Guthman, J. (2004). Agrarian dreams: The paradox of organic farming in California. Oakland: University of California Press.

Hassanein, N., \& Kloppenburg, J. R., Jr. (1995). Where the grass grows again: Knowledge exchange in the sustainable agriculture movement. Rural Sociology, 60(4), 721-740. https://doi.org/10.1111/j.1549-0831.1995.tb00603.x

Herman, A. (2015). Enchanting resilience: Relations of care and people-place connections in agriculture. Journal of Rural Studies, 42, 102-111. https://doi.org/10.1016/i.jrurstud.2015.10.003

Jorgensen, D. L. (2015). Participant observation. In R. A. Scott \& S. M. Kosslyn (Eds.), Emerging trends in the social and behavioral sciences (pp. 1-15). Hoboken, NJ: John Wiley \& Sons. https://doi.org/10.1002/9781118900772.etrds0247

Kroma, M. M. (2006). Organic farmer networks: Facilitating learning and innovation for sustainable agriculture. Journal of Sustainable Agriculture, 28(4), 5-28. https://doi.org/10.1300/J064v28n04 03

Lelekacs, J. M., O’Sullivan, J., Morris, M., \& Creamer, N. (2014). Incubator farms as beginning farmer support. Journal of Extension, 52(1), 1TOT7. Retrieved from https://joe.org/joe/2014february/pdf/JOE v52 1tt7.pdf

Liepins, R. (2000). New energies for an old idea: Reworking approaches to 'community' in contemporary rural studies. Journal of Rural Studies, 16(1), 23-35. https://doi.org/10.1016/S0743-0167(99)00042-X

Marsden, T. (2012). Third natures? Reconstituing space through place-making strategies for sustainability. International Journal of Sociology of Agriculture and Food, 19(2), 257-274. https://www.ijsaf.org/index.php/ijsaf

McMichael, P. (2014). Historicizing food sovereignty. Journal of Peasant Studies, 41(6), 933-957. https://doi.org/10.1080/03066150.2013.876999

Melone, B. (2006). Broadening the education infrastructure in organic agriculture for farmers. Crop Management, 5(1). Retrieved from https://dl.sciencesocieties.org/publications/cm/articles/5/1/CM-2006-0921-10-RV

Méndez, V. E., Bacon, C. M., \& Cohen, R. (2013). Agroecology as a transdisciplinary, participatory, and action-oriented approach. Agroecology and Sustainable Food Systems, 37(1), 3-18. https://www.tandfonline.com/toc/wisa21/current

Minkoff-Zern, L.-A. (2012). Pushing the boundaries of indigeneity and agricultural knowledge: Oaxacan immigrant gardening in California. Agriculture and Human Values, 29(3), 381-392. https://doi.org/10.1007/s10460-011-9348-4

New Entry Sustainable Farming Project. (2016). Incubator Farm Projects [Infographic]. Retrieved from https://nesfp.org/sites/default/files/uploads/nifti infographic 2016.pdf

Nerbonne, J. F., \& Lentz, R. (2003). Rooted in grass: Challenging patterns of knowledge exchange as a means of fostering social change in a southeast Minnesota farm community. Agriculture and Human Values, 20(1), 65-78. https://doi.org/10.1023/A:1022417608796

Niewolny, K. L., \& Lillard, P. T. (2010). Expanding the boundaries of beginning farmer training and program development: A review of contemporary initiatives to cultivate a new generation of American farmers. Journal of Agriculture, Food Systems, and Community Development, 1(1), 65-88. https://doi.org/10.5304/jafscd.2010.011.010

Ostrom, M. (2006). Everyday meanings of "local food": Views from home and field. Community Development, 37(1), 65-78. https://doi.org/10.1080/15575330609490155

Ostrom, M. (2015). From our Own Fields: Reconnecting Food, Farms, and Communities. In S. Salgado, A.M. Davidson, M. Dilon, \& M. Ostrom, Human nature: Sustainable farming in the Pacific Nortbwest (pp. 62-67). Seattle, WA: Minor Maters Books.

Ostrom, M. (2017). Understanding trends in consumer food system participation: Implications for agri-food movement mobilization and systems change in the Northwestern United States. In B. Elzen, A. M. Augustyn, M. Barbier, \& B. van Mierlo (Eds.), AgroEcological transitions: Changes and breakthroughs in the making (pp. 88-102). Wageningen, NL: Wageningen University \& Research. http://dx.doi.org/10.18174/407609 
Ostrom, M., DeMaster, K., Noe, E., \& Schermer, M. (2017). Values-based food supply chains from a transatlantic perspective: Exploring a middle tier of agri-food system development. International Journal of Sociology of Agriculture and Food, 24(1), 1-14. https://www.ijsaf.org/index.php/ijsaf

Ostrom, M., \& Donovan, C. (2016). Profile of small farms in Washington State: 2015 update. Washington State University Extension. Retrieved from http://cru.cahe.wsu.edu/CEPublications/TB39E/TB39.pdf

Overton, M. A. (2014). Growing new farmers: A survey of farm incubator programs in the United States (Master's thesis). Tufts University, Medford, MA.

Perez, J., Parr, D., \& Beckett, L. (2010). Achieving program goals? An evaluation of two decades of the Apprenticeship in Ecological Horticulture at the University of California, Santa Cruz. Journal of Agriculture, Food Systems, and Community Development, 1(1), 107-124. https://doi.org/10.5304/jafscd.2010.011.012

Reganold, J. P., Jackson-Smith, D., Batie, S. S., Harwood, R. R., Kornegay, J. L., Bucks, D., ... Willis, P. (2011). Transforming U.S. Agriculture. Science, 332(6030), 670-671. https://doi.org/10.1126/science.1202462

Röling, N. G., \& Wagemakers, M. A. E. (1998). Facilitating sustainable agriculture: Participatory learning and adaptive management in times of environmental uncertainty. Cambridge: Cambridge University Press.

TerAvest, D., Carpenter-Boggs, L., Thierfelder, C., \& Reganold, J. P. (2015). Crop production and soil water management in conservation agriculture, no-till, and conventional tillage systems in Malawi. Agriculture, Ecosystems \& Environment, 212, 285-296. https://doi.org/10.1016/J.AGEE.2015.07.011

U.S. Census Bureau. (2017) Selected social characteristics in the United States, American FactFinder: Skagit County, WA. Retrieved from https://factfinder.census.gov/faces/tableservices/jsf/pages/productview.xhtml?pid=ACS 17 5YR DP02\&src=pt

U.S. Department of Agriculture, National Agricultural Statistics Service [USDA NASS]. (2012). 2012 Census of Agriculture County Profile. Retrieved from https://www.nass.usda.gov/Publications/AgCensus/2012/Online Resources/ County Profiles/Washington/cp53057.pdf

USDA NASS. (2014). 2012 Census of Agriculture Highlights. Beginning farmers: Characteristics of farmers by years on current farm. Retrieved from https://www.nass.usda.gov/Publications/Highlights/2014/Beginning Farmers/index.php

USDA NASS. (2017). Value of Washington’s 2017 agricultural production totaled $\$ 10.6$ billion. Retrieved from https://www.nass.usda.gov/Statistics by State/Washington/Publications/Current News Release/2018/WA vop .pdf

Viva Farms. (n.d.). Home. Retrieved from http://www.vivafarms.org/

Wezel, A., Bellon, S., Doré, T., Francis, C., Vallod, D., \& David, C. (2009). Agroecology as a science, a movement and a practice. A review. Agronomy for Sustainable Development, 29(4), 503-515. https://doi.org/10.1051/agro/2009004

Winther, E.A., \& Overton, M. (2013). Farm incubator case studies: A supplement to the Farm Incubator Toolkit. New Entry Sustainable Farming Project. Retrieved from http://nesfp.nutrition.tufts.edu/resources/farm-incubatorcase-studies 